\title{
О.А. ЕРЁMЧЕНКО,
}

Российская академия народного хозяйства и государственной службы при Президенте РФ (Москва, Российская Федерация; e-mail: tatrics@mail.ru)

\section{B.Г. 3ИНОВ,}

Российская академия народного хозяйства и государственной службы при Президенте РФ (Москва, Российская Федерация; e-mail: zinov-v@yandex.ru)

\section{МИРОВАЯ ПРАКТИКА ГОСУДАРСТВЕННОЙ ПОДДЕРЖКИ ВЕНЧУРНОЙ ИНДУСТРИИ}

\footnotetext{
УДК: 338

https://doi.org/10.22394/2410-132Х-2021-7-1-51-65

Аннотация: Обобщен опыт и особенности государственных моделей поддержки корпоративного венчурного сектора в США, Китае и странах ЕС. Общим трендом развития венчурной отрасли для зарубежных стран является смещение фокуса венчурных фондов на инвестиции поздних стадий финансирования. Показано, что наибольшая эффективность государственных программ при стимулировании крупных компаний к инновационнотехнологическому развитию достигается при совместном финансировании стартапов, при создании фонда венчурных фондов, при внедрении налоговых льгот, нацеленных на компании с высоким потенциалом роста.

I Ключевые слова: венчурное финансирование, корпоративные венчурные фонды, инвестиции, государственные I программы поддержки, технологическое развитие, фонд фондов, налоговые льготы

- Благодарность: Исследование выполнено в рамках государственного задания РАНХиГС при Президенте РФ.

Для цитирования: Ерёмченко О.А., Зинов В.Г. Мировая практика государственной поддержки венчурной I индустрии. Экономика науки. 2021; 7(1):51-65. https://doi.org/10.22394/2410-132X-2020-7-1-51-65
}

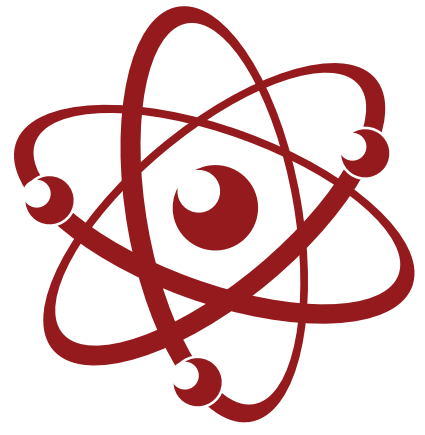

(C) О.А. Ерёмченко, В.Г. Зинов, 2021 r.

\section{ВВЕДЕНИЕ}

ля российской экономики в настоящее время задача раз-
вития неразрывно связана с наращиванием инвестици-
онной активности в высокотехнологичных секторах экои компаний с государственным участием. Эффективным механизмом поддержки формирования устойчивых преимуществ российских компаний в текущих условиях могло бы стать форсированное развитие венчурного капитала.

На государственном уровне необходимость развития корпоративных венчурных инвестиций в Росси впервые была зафиксирована в 2011 г. в поручениях Президента России по результатам заседания Комиссии при Президенте Российской Федерации по модернизации и технологическому развитию экономики России [1]. В августе 2014 г. были опубликованы Поручения по итогам встречи с членами Экспертного совета при Правительстве и представителями экспертного сообщества по вопросу развития инноваций, которые предусматривали выработку предложений «по развитию системы корпоративных венчурных фондов, осуществлению инвестиций в отраслевые фонды или институты развития, а также по вопросам приобретения инновационных компаний, ведущих инновационные разработки, в рамках осуществления программ инновационного развития государственных корпораций и компаний с государственным участием» [2].

В соответствии с поручением Правительства РФ, данным во исполнение подпунктов 1в и 2а поручения Президента России от 
1 апреля 2020 г. № Пр-614, Минэкономразвития России, Минфину России, необходимо «с учетом ранее данных поручений проанализировать практику создания и работы специальных подразделений и венчурных фондов государственных корпораций и компаний с государственным участием, а также иных инструментов, применяемых такими компаниями в целях финансирования развития высоких технологий», а также «представить предложения по созданию механизмов, позволяющих увеличить объем инвестиций государственных корпораций и компаний с государственным участием в венчурные фонды, в том числе за счет возможного инвестирования средств специализированным фондом в иные венчурные фонды, а также по возможности создания совместных венчурных фондов» [3].

Таким образом, руководство страны уже почти 10 лет стимулирует государственные корпорации и компании с государственным участием начать разработку механизмов увеличения их инвестиционной активности в венчурные фонды для вовлечения крупного бизнеса в инновационно-технологическое обновление.

Вместе с тем, подобные директивные указания должны быть скоординированы с развитием регламентации деятельности всех государственных институтов. Наиболее остро стоит вопрос об определении критерия, по которому используемые бюджетные средства перестают считаться таковыми в получаемой прибыли, которую можно использовать в венчурных инвестициях. Дополнительными ограничениями для активного использования корпоративного венчурного капитала являются недостаточность организационно-правового обеспечения и налоговых регуляторов, что снижает мотивацию руководителей государственных корпораций и компаний с государственным участием использовать этот вид инвестиционной активности.

Мировой опыт уже много лет доказывает, что непрерывный процесс инновационного развития, высокий уровень конкуренции за формирующиеся рыночные ниши новой технологической повестки и необходимость финансирования разработки товаров и услуг с высокой добавленной стоимостью на ранних этапах, требуют наличия соответствующих источников капитала, в том числе эффективно работающего венчурного сектора. Возникший в 60-х гг. XX в. в США механизм финансирования новых быстрорастущих инновационных компаний с использованием корпоративного венчурного капитала превратился в самостоятельную отрасль, специализирующуюся на инвестировании стартапов, которая активно используется крупнейшими корпорациями индустриально развитых стран для достижения экономических и стратегических целей. По данным аналитической платформы CB Insights, объем глобального рынка корпоративных венчурных инвестиций в 2020 г. составил более 73,1 млрд. долл. [4].

Динамика развития корпоративных венчурных фондов (КВФ) в мире в течение последних десятилетий демонстрирует убедительный рост. Согласно данным ежегодного сборника статистических данных «The 2018 Global CVC Report», составленного ведущим аналитическим агентством PitchBook (Сиэтл, США) и Национальной ассоциацией венчурного капитала США (NVCA), максимальное число КВФ сосредоточено в США. Рост объема инвестиций и количества сделок, совершенных КВФ в США с 2009 по 2019 гг., составил соответственно 8,6 раза (с 7,1 до 61 млрд. долл.) и 3,2 раза (с 50 до 1691 сделок). Характерно, что венчурный сектор в США также показал рост объема и количества сделок в 20092019 гг. соответственно в 4,5 раза (с 27,4 до 136,5 млрд. долл.) и 2,4 раза (с 4435 до 10777 сделок), причем пиковые значения пришлись также на 2018 г. Таким образом, рост объема инвестиций КВФ в США опережал общий рост венчурного инвестирования в 20092019 гг. в 2,2 раза и составил $44,7 \%$ от общего объема венчурного капитала [5].

В других странах мира корпоративный венчурный сектор также имеет тенденцию к росту. Если до 2016 г. более половины корпоративных венчурных сделок приходилось на Североамериканский регион, то в 2020 г. CB Insights фиксирует следующее соотношение числа сделок: Северная Америка - 1275 сделок, Азия - 1360 сделок, Европа - 623 сделок [5]. Лидирующие позиции по объему 
венчурного инвестирования занимают США и Китай, на которые приходится соответственно 44 и 40\% от общемирового объема венчурного капитала. На все остальные страны мира, включая страны Европейского союза, Индию (3-ю страну в мире по числе стратапов) и Россию, приходится суммарно лишь около 16\% глобального объема венчурных инвестиций. Такое распределение венчурного капитала делает политику США и Китая объектом пристального изучения с целью дальнейшей адаптации и использования в российской практике их опыта.

На протяжении последних лет опубликован ряд работ, акцентирующих внимание на корпоративном венчурном капитале [6], его роли в стратегическом управлении компаниями [7] и финансировании инноваций [8]. Вместе с тем, вклад государственного стимулирования корпоративных венчурных инвестиций все еще остается недостаточно освещенной в научной литературе областью исследований.

Целью настоящего исследования является анализ сложившейся в мире практики реализации моделей государственной поддержки венчурной индустрии применительно к российским условиям.

\section{СТИМУЛИРОВАНИЕ КОРПОРАТИВНОГО ВЕНЧУРНОГО СЕКТОРА В США}

Развитие корпоративного венчурного сектора в США началось задолго до перехода России к рыночной системе хозяйствования. Уже в середине $X X$ ст. активно развиваются походы к стимулированию корпоративных инноваций. Результаты эмпирических исследований одного из ведущих экспертов в мире в области корпоративных венчурных инвестиций Д. Лернера $[8,9]$ показывают небольшое влияние государственной политики на сектор инноваций и венчурные инвестиции крупных корпораций. В качестве основных точек роста, стимулирующих развитие этой отрасли, Лернер выделяет следующие:

1) Качество инфраструктуры, включающее как систему дорожного, авиа- и иного сообщения, логистическую систему, так и развитую правовую сферу, подготовку следующих поколений специалистов и другие элементы системы управления, которые в совокупности обеспечивают основу для формирования устойчивых связей и взаимодействия между участниками венчурной отрасли;

2) Превышение спроса на венчурный капитал над предложением;

3) Ориентация государственных органов поддержки на отрасли, доказавшие свою конкурентоспособность, и отрасли, возникающие стихийно, вместо инициатив и программ, поддерживающих долгосрочные политические решения.

4) Регулярный мониторинг и внедрение в практику лучших зарубежных практик по стимулирования инноваций в высокотехнологичных секторах экономики.

В настоящее время венчурный рынок США динамично развивается, показав рекордные темпы роста инвестиций в стартапы в 2020 г., несмотря на сложности, связанные с пандемией COVID-19. При этом Национальная ассоциация венчурного капитала США отмечает в своем отчете, что этот рост обусловлен преимущественно увеличением числа и объемов финансирования компаний на поздних стадиях, тогда как активность венчурных инвесторов на посевном этапе резко сократилось. Отраслевой срез сделок свидетельствует об активизации венчурного инвестирования в биотехнологии и фармацевтический сектор. По оценкам NVCA, в 2020 г. венчурные инвесторы вложили в американские стартапы 156,2 млрд. долл., заключив 12254 сделки [10].

Корпоративные венчурные инвесторы занимают лидирующие позиции по объему инвестируемых венчурных средств среди, так называемых, нетрадиционных венчурных инвесторов (частных инвесторов, компаний по управлению активами, государственных инвестиционных фондов и прочих инвесторов помимо венчурных фондов). Корпоративные венчурные сделки включают раунды, проводимые подразделениями корпораций, а также прямые инвестиции корпораций в акционерный капитал компаний с венчурным капиталом. На КВФ приходится $25,7 \%$ от общего числа сделок с привлечением венчурного капитала в США и 47,8\% от 
суммы сделок. В таблице 1 приведены данные, характеризующие объем и динамику показателей развития корпоративного венчурного сектора в США в течение пятнадцати лет (20052019 гг.), приведенные в ежегодном обзоре венчурной отрасли NVCA [10].

В США федеральные и региональные органы исполнительной власти реализуют масштабные программы поддержки высокотехнологичных стартапов через субсидирование венчурного капитала. Так, в 2018 г. губернатор штата Нью-Джерси Филип Мерфи объявил о плане по увеличению венчурных инвестиций в штате на 500 млн. долл. [11] через создание фонда «вечнозеленых» венчурных инвестиций. Планом было предусмотрено, что половина средств должна поступить от корпораций через аукцион налоговых кредитов (проданных со скидкой и субсидируемых государственными фондами), а остальная часть финансирования будет обеспечена за счет классических венчурных фондов.

В целом программы венчурного капитала в США делятся на два типа:
1) косвенное инвестирование - создание фонда фондов, когда государство инвестирует средства в создание венчурных фондов,

2) прямое инвестирование - совместное финансирование, когда государство непосредственно оказывает поддержку определенной компании.

На региональном уровне администрациями штатов не выработана эффективная стратегия распределения венчурного капитала для поддержки конкретных компаний, поэтому в США наибольшей популярностью пользуется метод создания фондов фондов за счет средств государственного и местного бюджетов.

Существенную роль в стимулировании инноваций и венчурного сектора, в том числе корпоративного венчурного финансирования, играют государственные программы. В качестве примера такой программы рассмотрим Государственную кредитную инициативу для малого бизнеса США (State Small Business Credit Initiative, SSBCl) - федеральную программу, находящуюся в ведении Министерства финансов США (U.S. Department of the

Таблица 1

Корпоративный венчурный сектор в США, 2005-2019 rr.

\begin{tabular}{|c|c|c|c|c|c|}
\hline Год & $\begin{array}{c}\text { Число } \\
\text { венчурных } \\
\text { сделок }\end{array}$ & $\begin{array}{c}\text { Число сделок } \\
\text { скрпоративным } \\
\text { венчурным } \\
\text { капиталом }\end{array}$ & $\begin{array}{c}\text { Доля сделок } \\
\text { корпоративным } \\
\text { венчурным } \\
\text { капиталом, \% }\end{array}$ & $\begin{array}{c}\text { Средний объем } \\
\text { венчурной сделки, } \\
\text { млн. долл. }\end{array}$ & $\begin{array}{c}\text { Средний объем сделки } \\
\text { скорпоратиным } \\
\text { венчуным капиталом, } \\
\text { млн. долл. }\end{array}$ \\
\hline 2005 & 2339 & 526 & 22 & 9,6 & 11,4 \\
\hline 2006 & 2663 & 587 & 22 & 10,7 & 16,4 \\
\hline 2007 & 3338 & 710 & 21 & 11,2 & 16,5 \\
\hline 2008 & 3622 & 726 & 20 & 9,9 & 14,7 \\
\hline 2009 & 2923 & 532 & 18 & 8,8 & 14,6 \\
\hline 2010 & 3462 & 596 & 17 & 8,4 & 15,5 \\
\hline 2011 & 4653 & 775 & 17 & 9,5 & 18,7 \\
\hline 2012 & 5620 & 903 & 16 & 7,2 & 15,2 \\
\hline 2013 & 6555 & 1209 & 18 & 7,2 & 22,3 \\
\hline 2014 & 7236 & 1486 & 21 & 10,2 & 26,6 \\
\hline 2015 & 7182 & 1613 & 22 & 12,1 & 26,6 \\
\hline 2016 & 6296 & 1559 & 25 & 13,0 & 25,9 \\
\hline 2017 & 6750 & 1667 & 25 & 13,4 & 42,2 \\
\hline 2019 & 7333 & 1846 & 25 & 21,1 & 36,2 \\
\hline
\end{tabular}

Источник: NVCA 2020 Yearbook 
Treasury), реализованную в 2011-2017 гг. [12]. Объем финансирования за счет средств госбюджета составил 1,5 млрд. долл., а суммарный объем инвестиций в малые и средние компании, включающий частное финансирование и заемные средства, достиг 15 млрд. долл. В рамках реализации SSBCl в каждом штате были созданы подпрограммы (муниципальные программы) в следующих направлениях: доступ к капиталу, гарантия ссуды, дополнительная поддержка, участие в ссуде, венчурный капитал.

Рассмотрим муниципальную программу поддержки венчурного капитала в одном из 38 штатов, реализовавших муниципальные программы поддержки венчурной отрасли. Штат Флорида находится на втором месте по объему выделенных средств и первый среди штатов, реализовавших программу SSBCl. Суммарно на программы кредитной поддержки СМП и программу венчурного капитала во Флориде было израсходовано 97,7 млн. долл. [13].

Муниципальная программа поддержки венчурного сектора получила название Venture Capital Program, еe бюджет составил 43,5 млн. долл. Административные функции по управлению венчурным капиталом были возложены на Florida First Partners - совместное предприятие двух частных компаний Arsenal Venture Partners и Credit Suisse, которые в соответствии с контрактом действуют от лица Департамента экономических перспектив штата Флорида.

Программа венчурного капитала (BK) штата Флориды была разработана для покрытия потребности в инвестициях малых компаний на ранней стадии, имеющих высокий потенциал роста при первоначальном и последующих раундах финансирования. Критерием отбора являлся объем выручки компании, который должен был составлять менее 5 млн. долл. При этом в случае осуществления стратегически важных сделок, инвестиционный менеджер имел возможность одобрять инвестирование за пределами этого диапазона.

В обязанности управляющего органа программы ВК входил поиск поставщиков, проведение комплексной проверки, закрытие инвестиционных сделок, а также управление и поддержка роста объектов инвестиций. По состоянию на 31.12.2015 г. было израсходовано 21,6 млн. долл. государственных средств, при этом общая сумма привлеченных инвестиций, в том числе за счет крупных компаний, составила 113 млн. долл. [13]. Средний объем одной инвестиционной сделки составил 2,58 млн. долл. Отметим, что соотношение объемов финансирования из муниципальных программ и со стороны частного сектора существенно отличалось у разных штатов. Если во Флориде соотношение средств госбюджета к частным инвестициям составило 1:5, то в Луизиане на 1,3 млн. долл. средств госбюджета пришлось 15,9 млн. долл. частных инвестиций и составило 1:12.

Анализ итогов реализации программы $\mathrm{SSBCl}$ в различных штатах позволил сделать следующие выводы о перспективах использования государственного стимулирования венчурного сектора с участием корпораций:

- При реализации государственных программ финансового стимулирования венчурной отрасли и корпоративного венчурного финансирования необходимо по примеру частных венчурных и инвестиционных фондов резервировать капитал для участия в последующих инвестиционных раундах для всех поддержанных компаний.

- Решающим фактором успеха запуска подобных программ в формате фонда является правильный выбор топ-менеджмента управляющей фондом компании. Руководитель такой компании должен обладать релевантным опытом и обширными профессиональными связями, которые позволят выбрать наилучшую инвестиционную стратегию и привлечь частный капитал в достаточном объеме.

- Созданные в рамках муниципальных программ фонды венчурного капитала играют важнейшую роль для укрепления доверия на рынке и обеспечения согласованности в операциях на рынке между всеми участниками сделок.

- Создание венчурного фонда за счет средств бюджета для решения региональных задач может быть эффективным инструментом формирования частного капитала и экономического развития, при этом размер фонда 
имеет решающее значение для достижения финансовых результатов программы.

- Необходимо активно способствовать созданию венчурных фондов за счет государственных средств в штатах с отсутствием или незначительным количеством венчурных фондов. Следует принимать во внимание, что в регионах с незначительным числом фондов структура муниципальных программ поддержки должна быть направлена на создание структуры, охватывающей все стадии финансирования стартапов. Инвесторы на посевных стадиях инвестирования должны иметь уверенность в возможности привлечения последующих раундов финансирования.

- Важную роль в реализации SSBCl имеет разработка планов преемственности руководящих позиций в узкоспециализированных программах поддержки венчурного сектора. В случае, когда этот вопрос недостаточно проработан на начальном этапе, смена руководителя может привести к досрочному прекращению реализации программы, даже если были получены первые положительные результаты.

- Критическим барьером успешной реализации программ господдержки венчурного капитала может стать конфликт интересов между руководством штата, созданными фондами и соинвесторами (частными компаниями, венчурными фондами и др.). В этой связи целесообразным представляется на начальном этапе запуска программ детально прорабатывать и учитывать все возможные фактические или потенциальные разногласия между заинтересованными сторонами.

Наряду с масштабными государственными программами поддержки венчурного капитала, в США, в отличие от многих других стран, отсутствует особый налоговый режим для венчурной отрасли на общенациональном уровне. В стране нет федеральных налоговых льгот, хотя в ряде штатов такие послабления зафиксированы на местном уровне и составляют до 50\% (для налогоплательщиков кроме корпораций) [14].

Следует также отметить, что правительственными структурами США применяются как стимулирующие методы для привлечения капитала в венчурную отрасль и приоритетного развития высоких технологий, так и ограничения на прямые инвестиции. В первую очередь ограничения связаны с контролем за иностранным владением в компаниях в критически важных отраслях или компаниям, имеющим доступ к конференциальным и личным данным граждан страны. Надзорные функции по соблюдению требований к обеспечению национальной безопасности возложены на межведомственный Комитет по иностранным инвестициям США (The Committee on Foreign Investment in the United States, CFIUS), уполномоченный запрашивать документы о сделках с привлечением иностранного капитала и запрет или аннулирование таковых в случае потенциальной угрозы безопасности страны. С 1 июня 2020 г. все венчурные сделки с привлечением зарубежных инвесторов должны быть зарегистрированы в виде уведомления или подачи декларации через специализированный портал CFIUS Case Management System [15].

\section{УПРАВЛЕНИЕ КОРПОРАТИВНЫМ ВЕНЧУРНЫМ КАПИТАЛОМ В ЕВРОПЕЙСКИХ СТРАНАХ}

Многие из наиболее успешных рынков венчурного капитала стимулируются за счет государственной поддержки [16]. По сравнению с США, страны Европы испытывают дефицит частного венчурного финансирования, что еще больше усиливает роль государства в развитии венчурной отрасли. В обзоре Owen R. с соавторами [17], посвященном роли государственных венчурных фондов в Великобритании, отмечено увеличение объема инвестиций в такие фонды после глобального финансового кризиса 2008-2009 гг. Авторы связывают эту тенденцию с желанием государства оказать поддержку инновационным компаниям и способствовать диверсификации производств. При этом особое внимание уделялось стартапам на начальных этапах инвестирования: потребность в создании в Великобритании венчурных фондов за счет средств государственного бюджета обусловлена, в первую очередь, необходимостью обеспечить преемственность и поддержку финансирования стартапов на всех этапах развития [18]. 
Современную ситуацию с венчурными инвестициями в странах Европы отражают данные, опубликованные в 2020 г. в совместном отчете Mountside Ventures и ALLOCATE [19], и посвященные результатам исследования европейских компаний, желающих привлечь венчурные инвестиции, и инвесторов, которые активно вкладывают средства в растущую экосистему венчурных инвестиций. Обобщение предоставленных сведений позволяет выявить актуальные тренды развития отрасли.

В исследовании [19] представлены ответы 63 респондентов, которые в течение последнего года встречались с более чем 2000 потенциальными получателями венчурного капитала и в совокупности инвестировали в 360 венчурных фондов в 2018-2020 гг. Доли отдельных типов респондентов опроса от общего числа опрошенных инвесторов распределены в следующем соотношении:

- фонды фондов 36\%,

- семейные фонды и частные лица 28\%,

- корпоративные и пенсионные фонды $18 \%$,

- государственные агентства (институты инновационного развития) $8 \%$,

- эндаумент фонды университетов 5\%,

- другие венчурные фонды 5\%.

Фонды фондов создаются в качестве посредника, позволяющего крупным институциональным инвесторам проводить анализ предложений для вложения средств, получать доступ к венчурным инвестициям и управлять ими. Вклад в венчурную отрасль фондов фондов составил суммарно около 1 млрд. евро в 2018 г., что больше, чем вклад других инвесторов (без учета инвестиций государственных институтов развития) [20].

Семейные фонды и частные лица также являются значительным источником венчурного капитала. По данным World Wealth Report [21], богатые семьи и частные лица контролируют около 36 трлн. евро во всем мире.

Эндаумент фонды в европейских странах демонстрируют меньшую по сравнению с американскими эндаумент фондами активность и склонность к риску, потому не покупают большие доли в венчурных активах. Вместе с тем этот тип инвесторов имел наибольший рост в европейском венчурном капитале в 2014-2018 гг. [21].

В то время как доходность для инвесторов является, несомненно, самым важным фактором принятия решений, респонденты определили также следующие ключевые причины, по которым они стремятся инвестировать в венчурный капитал: диверсификация портфеля и возможность размещения капитала в более поздних раундах финансирования стартапов.

Как отмечают исследователи, респонденты выражают изрядную долю разочарований в венчурных инвестициях, в связи с тем, что они часто встречаются с такими особенностями венчурной индустрии как:

- недостаточный инвестиционный опыт управляющих венчурными фондами, которые кажутся не в полной мере компетентными и вызывают недоверие инвесторов;

- отсутствие прозрачности в венчурных фондах, в которые респонденты уже инвестировали средства;

- непонимание венчурными фондами своей компетенции и стратегии;

- пренебрежение построением долгосрочных отношений.

Стимулирование инноваций и поддержка устойчивого развития рынка, независимо от экономических циклов, с помощью государственной поддержки массовых европейских венчурных рынков повышает их показатели, делая более привлекательными для частных инвесторов, число которых постоянно растет.

Треть венчурных фондов, принявших участие в опросе, получали финансирование от государственных фондов фондов или других государственных структур. При этом, четверть из них являются новичками на венчурном рынке.

В 2018 г. объем средств, вложенных европейскими венчурными инвесторами, составил 23 млрд. евро, тогда как аналогичный показатель для американского рынка составил 111 млрд. евро. В 2019 г. эти цифры составили 30 млрд. евро (пятилетний максимум для Европы) и 113 млрд. евро для США.

Необходимыми факторами развития отрасли признаны следующие: более благоприятное для бизнеса регулирование, меньшее налогообложение, гибкость рабочей силы 
и менталитет принятия серьезных рисков, которые могут положительно сказаться на европейской венчурной среде.

Откликом на выводы проведенного исследования стало открытие в Германии нового фонда фондов на 10 млрд. евро под названием Future Fund для экосистемы стартапов, которые традиционно боролись за получение больших инвестиций от местных источников, но в результате чаще полагались на крупные иностранные венчурные фирмы [22]. Деньги будет распределять институт развития $\mathrm{KfW}$ (аналог ВЭБа в Германии) и предоставлять капитал венчурным фондам. Часть капитала поступит также в наднациональный фонд фондов European Investment Fund. Германия надеется на соинвестиции в 20 млрд. евро со стороны частных инвесторов. Таким образом объем дополнительно привлеченных инвестиций составит около 30 млрд. евро к 2030 г.[23].

Аналогичное решение утверждено во Франции: Правительство приняло решение о выделении 2 млрд. евро в капитал венчурных фондов с целью поддержки растущих стартапов на поздних стадиях. В целом одобрен пакет мер объемом 5 млрд. евро по ослаблению ограничений инвестиций институциональных инвесторов, из них 2 млрд. евро поступят в венчурные фонды поздних стадий, а 3 млрд. евро - в фонды, которые торгуют на бирже.

В Великобритании основополагающую роль в выстраивании системы венчурной отрасли имеют три государственных фонда венчурного капитала: Enterprise Capital Funds, UK Innovation Investment Fund $и$ Angel Coinvestment Fund. Работа всех трех фондов построена на использовании гибридных схем совместного инвестирования [24], и направлена на стимулирование инвестиций в инновационные и быстрорастущие британские компании на разны этапах. Суммарный объем инвестирования всех трех фондов с 2006 г. обеспечил финансирование более 1,1 млрд. фунтов стерлингов на посевных и ранних стадиях [17].

Фискальные меры стимулирования инновационной активности компаний являются одним из наиболее популярных и часто используемых инструментов в разных странах. В странах EC политика поддержки компаний в высокотехнологичных отраслях носит системный характер и реализуется как в рамках общих для всех стран ЕС программ, так и в рамках программ отдельных стран.

Исторически малый и средний бизнес в европейских странах зависел преимущественно от банковского финансирования, однако глобальные кризисы ограничили привлечение банковского капитала и повлекли поиск иных источников финансовых ресурсов, в том числе, венчурных фондов и бизнес-ангелов.

Налогообложение играет значительную роль в поддержке или сдерживании венчурных инвестиций. При этом изменение ставки или порядка взимания налога на прибыль оказывают незначительное влияние на привлечение венчурного капитала, поскольку не приводит к перераспределению дивидендов. Ha решение потенциального частного инвестора большее значение оказывает налоговый режим прироста капитала или убытков, полученных при выбытии инвестиции, влияя на склонность инвестора к риску. Налоговые льготы на прирост капитала или предоставление компенсации убытков на более благоприятной основе могут способствовать снижению рисков для инвестиций в молодые, растущие и инновационные предприятия [25].

В исследовании налоговой политики в области стимулирования венчурного финансирования Европейской Комиссии была обобщена практика по разработке налоговых льгот на основании анализа 46 налоговых льгот, используемых в 36 странах Европы [25]. Итоговыми тезисами, которые могут быть имплементированы в дальнейшую практику стран ЕС и других государств признаны следующие:

- Схемы налогообложения в области венчурного финансирования должны способствовать снижению инвестиционных рисков, например, через авансовые налоговые льготы или возмещение убытков на более благоприятной основе, чем это предусмотрено базовыми условиями действующей налоговой системы.

- Структура налоговых льгот должна быть нацелена на компании с высоким потенциалом роста, и опираться на количественные критерии отбора объектов поддержки, такие как возраст компании, размер и численность 
персонала. Следует отказываться от схем предоставления адресных налоговых льгот, поскольку государственные органы не имеют достаточной информации для успешного выполнения анализа заявок и/или сравнения секторов и технологий.

- В качестве целевого индикатора реализации государственной политики в области стимулирования венчурного капитала должны использоваться квалификационные критерии, связанные с производительностью.

- Эффективность налоговых льгот можно повысить за счет сочетания их стабильности и осведомленности целевых инвесторов.

- Внедрение систематического мониторинга и оценки затрат и экономических результатов внедрения налоговых льгот для венчурного капитала.

Важными условиями достижения экономического эффекта от внедрения налоговых льгот по стимулированию венчурного финансирования являются:

- Обеспечение соответствия условий льготной поддержки потребностям конкретной страны или региона, включая правовой, институциональный и экономико-политический контекст.

- Разработка и тестирование любых изменений до внедрения на федеральном уровне.

- Сопровождение любых изменений персональной ответственностью лиц, в чьем ведении находится администрирование льготных схем в органах исполнительной власти.

- Проведение осведомительной компании для потенциальных инвесторов, включая предварительное объявление внедрения налоговых льгот и обеспечение постоянной информационной поддержки решений.

- Проведение систематического мониторинга и оценки фискальных схем.

\section{РАЗВИТИЕ КОРПОРАТИВНОГО ВЕНЧУРНОГО СЕКТОРА В КИТАE}

Исторически в Китае значительную роль в формировании экосистемы стартапов как платформы продвижения инноваций на внутренний и глобальные рынки играли вузы. Во время первой волны стартапов, начавшаяся в 1990-х гг., именно научно-исследовательские центры и университеты начали предоставлять технологии и начальный капитал. В этот период 85\% финансирования новых технологических компаний, основанных в Пекине, было обеспечено за счет инвестиций материнских исследовательских центров или университетов, из которых вышли эти компании [26]. Банки присоединились к поддержке стартапов позднее и обеспечили приток инвестиции на более поздних раундах привлечения капитала. Венчурные фонды, поддерживаемые государством, корпоративным и иностранным капиталом начали создаваться лишь в 1998 г.

В настоящее время на Китай приходится более $40 \%$ глобальных венчурных инвестиций (Силиконовая долина в США по-прежнему занимает лидирующие позиции в мире с 44\%) [27]. Большая часть венчурных инвестиций приходится на технологических гигантов, таких как Alibaba, Baidu и Tencent. Вместе с тем, в настоящее время китайское правительство проводит политику разделения крупнейших корпораций и стимулирует консолидацию небольших компаний. В первую очередь это связано с подавлением теневой банковской системы, оцененной в 12,9 трлн. долл. [27].

В качестве одного из инструментов реализации государственной политики в различных областях Китай, как и другие страны, использует систему средне- и долгосрочных программ в стратегически важных отраслях. Такой же поход применен и к стимулированию инноваций госкомпаний.

В 2015 г. китайским правительством была принята десятилетняя государственная стратегия - план развития промышленности, получившая название «Сделано в Китае 2025». Конечной целью ее реализации должно стать достижение страной доминирующего положения на глобальных высокотехнологичных рынках через внедрение государственных субсидий, мобилизацию государственных предприятий и приобретение интеллектуальной собственности за рубежом. Еще одним результатом должно стать снижение зависимости Китая от зарубежных технологий. Программа «Сделано в Китае 2025» фокусирует усилия 
на развитии 10 отраслей национальной промышленности, занимающие центральную роль в Индустрии 4.0, в числе которых электромобили и другие транспортные средства на новой энергии, информационные технологии следующего поколения и телекоммуникации, передовая робототехника и искусственный интеллект. Конкретный целевой показатель успеха реализации программы - достижение к 2025 г. 70\% самообеспеченности в высокотехнологичных отраслях [28].

В реализацию программы «Сделано в Китае 2025» вовлечено более 1,5 тысяч государственных инвестиционных фондов и фондов с государственным участием, осуществляющих инвестиции в тысячи стартапов в приоритетных отраслях развития национальной промышленности. По данным консалтингового агентства Zero2IPO Research, к концу 2018 г. в Китае насчитывалось более 1600 государственных фондов с капиталом более 584,8 млрд. долл., и ежемесячно создается 7-8 новых фондов, управляемых государством, уставной капитал каждого фонда в среднем составляет 361 млн. долл. (данные по [28]). Фонды финансируются как за счет средств государственного и местного бюджета, государственных финансовых учреждений, так и за счет ресурсов крупных частных компаний, поощряемых к участию в подобных инвестициях. При этом система управления этими фондами, их взаимодействие и подотчетность является непрозрачной, большинство из них не имеют собственных сайтов, а детали сделок не раскрываются (за исключением случаев с инвестированием в компании, зарегистрированные на фондовой бирже) [28].

Государственные венчурные фонды инвестируют преимущественно в стартапы, но в некоторых случаях также участвуют в сделках слияний и поглощений и инвестируют в листинговые компании. Максимальная доля инвестиций приходится на две области: «инновации и предпринимательство» и «развивающиеся стратегические отрасли и передовые отрасли обрабатывающей промышленности», а самым значимым и по объему ресурсов, и по важности для китайской экономики является Национальный инвести- ционный фонд индустрии интегральных микросхем (Большой Фонд).

Большой Фонд со стартовым объемом капитала в 20 млрд. долл. был создан в 2014 г. Его акционерами стали Министерство финансов Китая (доля в капитале - 36\%) и государственные компании China Development Bank Capital Corporation (22\%), China Tobacco (11\%), Beijing E-Town International Investment and Development Corporation (10\%) и China Mobile (5\%) [28]. Лишь за первый год работы фонд проинвестировал средства в 70 компаний. Основная цель Большого фонда - это создание национальных чемпионов в области полупроводников.

Анализ литературных источников показал, что в Китае используют как традиционные подходы к стимулированию корпоративных инноваций, в том числе за счет создания венчурных фондов и дивизионов, так и развивают новые, нестандартные подходы к укреплению инновационного потенциала. Примером такого подхода может служить распространенная в Китае практика ротации, при которой должностных лиц, занимающих служебные посты с одинаковым рейтингом, регулярно перемещают между собой.

Официальная система управления кадровыми ресурсами и система фискальной децентрализации привели к тому, что должностные лица в отдельных регионах и городах контролируют большие объемы экономических ресурсов, имеют возможность принимать относительно независимые решения и перераспределять ресурсы между субъектами рынка. Ротация чиновников в регионах зависит от решения центрального правительства Китая и основывается на показателях экономической эффективности, достигнутых на предшествующей позиции. Таким образом чиновники заинтересованы в достижении краткосрочных экономических целей и зачастую стимулируют предприятия реального сектора экономики инвестировать средства в расширение производства, а не в развитие инноваций для достижения средне- и долгосрочных экономических выгод [30]. Вместе с тем, в Китае осознана ключевая роль технологических инноваций в достижении устойчивого экономического 
развития страны. Экстенсивная модель использования ресурсов исчерпала себя: капитал, рабочая сила и другие факторы производства признаны неустойчивым базисом для дальнейшего экономического роста.

В текущей парадигме развития Китая корпоративные инновации и инвестиции в новые технологии рассматриваются как микро-основа для устойчивого экономического роста и основная движущая сила национального инновационного суверенитета. Такой подход требует систематического улучшения модели стимулирования корпоративных инноваций со стороны региональных и местных властей.

Местные органы власти играют решающую роль в системе инвестиций в науку и технологии Китая. Разворачивание долгосрочных инвестиционных и венчурных программ увеличивают финансовые риски крупных корпораций, а расходы на НИОКР могут превысить запланированные показатели. Отсутствие возможности точного прогнозирования получения и коммерциализации результатов исследований и разработок на внутреннем и внешних рынках, нестабильность внешних факторов могут привести к нехватке капитала и невозможности внедрения новшеств в технологические процессы.

Совокупность этих факторов обеспечивают теоретическую основу для вмешательства государства и поддержки инновационной деятельности китайских компаний. Местные власти могут влиять на корпоративное инвестиционное поведение в сфере НИОКР, обеспечивая часть расходов на финансирование научно-технологических проектов. Также поддержка корпоративных инвестиций в технологическое развитие осуществляется через финансовую поддержку (как прямую, так и через субсидирование) приоритетных инновационных областей.

В целом для китайских компаний характерна поддержка тесных связей с органами государственного управления - правительство Китая имеет большое влияние на текущую операционную деятельность компаний, улучшая возможности регионального экономического развития и направляя факторы производства в НИОКР и поощряя предприятия во внедрении технологических инноваций.
Исследование, проведенное в 2020 г. Shi X. с соавторами [31] показало, что ротация губернаторов в Китае в значительной степени оказывает положительной влияние на корпоративные инновации, в том числе влечет за собой рост объема и качества инвестиций предприятий в НИОКР.

Во-первых, официальная ротация может способствовать корпоративным инновациям за счет обмена виденьем экономического развития быстро развивающихся регионов. Чиновники из развитых регионов могут принести свой опыт и улучшить региональную и экономическую среду, эффективность рыночных механизмов на новых местах.

Во-вторых, одной из целей ротации является снижение коррупции, а это в свою очередь положительно влияет на корпоративные инновации. Такой эффект достигается за счет того, что в условиях антикоррупционных моделей взаимодействия с органами власти компании снижают затраты на поиск политических связей, что увеличивает стимулы для корпоративных инноваций.

Таким образом официальная ротация чиновников стимулирует экономический рост. Ротация способствует росту инвестиции компаний в НИОКР, увеличивает объем ноу-хау и патентных заявок на изобретения и полезные модели, что приводит к росту регионального ВВП, в том числе за счет корпоративных инноваций.

\section{выводы}

Обобщая опыт и особенности управления венчурным сектором в зарубежных государствах, следует, прежде всего, отметить стабильный рост числа и объема сделок с участием венчурного капитала и корпоративного венчурного капитала в каждой из рассмотренных стран.

Общим трендом развития венчурной отрасли для зарубежных стран является смещение фокуса венчурных фондов на инвестиции поздних стадий финансирования. Глобальный отраслевой срез сделок за 2020 г. ожидаемо показал рост интереса инвесторов к стартапам в области биотехнологий и фармацевтике. Для китайских венчурных инвесторов 
приоритетом являются полупроводники, а также две стратегические области - «инновации и предпринимательство» и «развивающиеся стратегические отрасли и передовые отрасли обрабатывающей промышленности».

В качестве точек роста, стимулирующих развитие венчурных инвестиций крупных компаний, зарубежными исследователями называются: качество инфраструктуры (включая логистику, правовую систему и кадровую подготовку); превышение спроса на венчурный капитал над предложением; ориентацию господдержки на наиболее конкурентоспособные отрасли; систематический мониторинг лучших зарубежных практик и их внедрение в собственную систему стимулирования инноваций.

Государственная модель поддержки корпоративного венчурного сектора каждой из рассмотренных стран формируется в соответствии с историческими предпосылками и социально-экономической средой.

В Китае исторически значима роль университетов и научно-исследовательских центров, которые первыми начали предоставлять капитал для развития новых технологических компаний. При этом в настоящее время китайское правительство проводит политику разделения крупнейших корпораций и стимулирует консолидацию небольших компаний.

В США государство в лице органов исполнительной власти и руководства отдельных штатов проводило активную политику стимулирования инвестирования частного капитала при реализации масштабных федеральных и региональных программ поддержки высокотехнологичных стартапов через субсидирование венчурного капитала. В качестве одного из инструментов используется привлечение средств корпораций через аукционы налоговых кредитов (проданных со скидкой и субсидируемых государственными фондами). При этом в США налоговые льготы в отношении венчурного капитала отсутствуют на федеральном уровне, но каждый штат самостоятельно снижает до 50\% налоговую нагрузку на компании.

В странах EC политика государственной поддержки компаний в высокотехнологичных отраслях носит системный характер и реализуется как в рамках общих для всех стран программ, так и в рамках программ отдельных стран.

В целом фискальные меры стимулирования инновационной активности компаний являются одним из наиболее популярных и часто используемых инструментов. Роль государства в регулировании и стимулировании венчурного рынка становится все более заметной. Если ранее главенствующей парадигмой было предоставление участникам рынка максимальной свободы действий и предполагалось, что саморегулирование приведет к получению максимальных выгод в рамках либерального подхода, то в настоящее время государственные структуры все чаще становятся головными инициаторами запуска программ поддержки, реализуя задачи по стимулированию инвестиций в сектора Индустрии 4.0.

Анализ государственных программ поддержки венчурного капитала через прямое и косвенное инвестирование показал, что финансирование создания фондов венчурных фондов имеет больший экономический эффект по сравнению с прямыми точечными инвестициями конкретных компаний. Общей проблемой в данном случае является отсутствие возможности выработать эффективную систему распределения бюджетных ресурсов, а также отсутствие необходимой информации о всех потенциальных и/или подавших заявки претендентов на получение поддержки компаний.

\section{ЛИТЕРАТУРА}

1. Перечень поручений Президента РФ по итогам Петербургского международного экономического форума от 14.06.2017 г. № Пр-1132 (2017) / Официальный сайт Президента России. http://www.kremlin.ru/acts/assignments/ orders $/ 54793$.
2. Поручения по итогам встречи с членами Экспертного совета при Правительстве и представителями экспертного сообщества по вопросу развития инноваций (2014) / Официальный сайт Правительства России, 13.08.2014. http://government. ru/orders/selection/401/14277. 
3. Перечень поручений по итогам встречи с ведущими российскими инвесторами (утв. Президентом РФ 01.04.2020 г. №Пр-614) (2020) / Консультант Плюс. http://www.consultant.ru/ document/cons_doc_LAW_349280.

4. The 2020 Global CVC Report (2021) / CB Insights, 16.03.2021. https://www.cbinsights.com/research/ report/corporate-venture-capital-trends-2020.

5. The 2018 Global CVC Report (2019) / CB Insights. https://www.cbinsights.com/research/report/corporate-venture-capital-trends-2018.

6. Jean L., Sahut J., Teulon F. (2011) What is the real role of corporate venture capital? // International Journal of Business. 16(4):367-382.

7. Chesbrough H.W., Tucci C.L. (2004) Corporate Venture Capital in the Context of Corporate Innovation / DRUID Summer Conference 2004. Elsinore, Denmark.

8. Lerner J., Nanda R. (2020) Venture Capital's Role in Financing Innovation: What We Know and How Much We Still Need to Learn / Working Paper 20-131. Harvard Business School. 32 p.

9. Lerner J. (2009) Boulevard of Broken Dreams. Why Public Efforts to Boost Entrepreneurship and Venture Capital Have Failed - and What to Do about It / Princeton University Press.

10. Venture Monitor Q4 2020 (2021) / PitchBook, NVCA. $37 \mathrm{p}$.

11. Corasaniti N. (2018) With $\$ 500$ Million, New Jersey Wants to Invest in Your Start-Up / The New York Times, 01.10.2018. https://www.nytimes. com/2018/10/01/nyregion/new-jersey-venturecapital-murphy.html.

12. State Small Business Credit Initiative (2021) / U.S. Department of the Treasury. https://www.treasury.gov/resource-center/sb-programs/Pages/ ssbci.aspx.

13. Appendices. Program Evaluation of the U.S. Department of Treasury State Small Business Credit Initiative Center for Regional Economic Competitiveness \& Cromwell Schmisseur (2016) / U.S. Department of the Treasury. https://www.treasury.gov/resource-center/ sb-programs/Documents/SSBCl\%20Program\%20 Evaluation\%202016\%20-\%20Appendices.pdf.

14. Investment Taxation. Venture Capital: The U.S. Tax Regime For Venture Capital (2021) / LowTax. https://www.lowtax.net/us-tax-guide/investment/ the-us-tax-regime-for-venture-capital.html.

15. The Committee on Foreign Investment in the United States (2021) / U.S. Department of the Treasury. https://home.treasury.gov/policy-issues/international/the-committee-on-foreign-investment-in-theunited-states-cfius.

16. Lerner J. (2010) The future of public efforts to boost entrepreneurship and venture capital // Small Business Economics. 35(3):255-264.

17. Owen R., North D., Mac C. (2019) The Role of Government Venture Capital Funds: Recent lessons from the UK experience. https://onlinelibrary.wiley. com/doi/full/10.1002/isc.2247.

18. From Funding Gaps to Thin Markets: UK Government Support for Early-Stage Venture Capital (2009) / BVCA Report for NESTA. 36 p.

19. The Capital Behind Venture 2020. Insights from the investors behind Europe's Venture Capital Ecosystem (2021) / Mountside Venture, Allocate. 27 p.

20. The State of European Tech 2019 Report (2020) / Atomico, 2020.

21. World Wealth Report (2020) / Capgemini. https:// worldwealthreport.com.

22. Serenelli L. (2021) German government quick starts fund with $€ 10 \mathrm{bn}$ for 'future tech' / IPE, 30.03.2021. https://www.ipe.com/news/germangovernment-quick-starts-fund-with-10bn-for-futuretech/10051949.article.

23. Partington M. (2020) Germany launches $€ 10$ bn 'Future Fund' for startups. But will it go far enough? / Sifted, 14.12.2020. https://sifted.eu/articles/germany-future-fund-startups.

24. Murray G. C. (2007) Venture Capital and Government Policy / In Handbook of Research on Venture Capital, edited by H. Landstrom. Pp. 113-151.

25. Effectiveness of tax incentives for venture capital and business angels to foster the investment of SMEs and start-ups. Final Report (2017) / European Communities. https://ec.europa.eu/taxation_customs/sites/taxation/files/taxation_paper 69 vc-ba.

26. Blank S. (2021) China Startup Report: Introduction to Chinese Venture Capital (Part 3 of 5) / StartupGrind. https://www.startupgrind.com/blog/chinastartup-report-introduction-to-chinese-venture-capital-part-3-of-5.

27. Zinser S. (2021) The Global Reach of China's Venture Capital / The Diplomat, 21.01.2021. https:// thediplomat.com/2021/01/the-global-reach-ofchinas-venture-capital.

28. McBride J., Chatzky A. (2019) Is 'Made in China 2025' a Threat to Global Trade? // Council of Foreign Relations. 13.05.2019. https://www.cfr. org/backgrounder/made-china-2025-threat-global-trade\#: : : text=China\%202025\%20sets\%20specific\%20targets, dominant\%20position $\% 20$ in $\% 20$ global\%20markets.

29. Huang T. (2019) Government-Guided Funds in China: Financing Vehicles for State Industrial Policy / PIIE, 17.06.2019. https://www.piie.com/blogs/ china-economic-watch/government-guided-fundschina-financing-vehicles-state-industrial-policy.

30. Wu Y.B. (2017) Distorted investment under Chinese style decentralization // Economics Research Journal. 52(06): 137-152 (in Chinese).

31. Shi X., Bu D., Zhang C. (2020) Official rotation and corporate innovation: Evidence from the governor rotation // China Journal of Accounting Research. 13(4):361-385. 


\title{
Информация об авторах
}

Ерёмченко Ольга Андреевна - старший научный сотрудник Центра научно-технической экспертизы, Российская академия народного хозяйства и государственной службы при Президенте РФ; Scopus Author ID: 5581 1482100, ORCID: 0000-0001-5964-9080 (Российская Федерация, 119571, г. Москва, пр. Вернадского, д. 82 ; e-mail: tatrics@mail.ru)

Зинов Владимир Глебович - доктор экономических наук, кандидат технических наук, главный научный сотрудник Центра научно-технической экспертизы, Российская академия народного хозяйства и государственной службы при Президенте РФ; Scopus Author ID: 7003590126, ORCID: 0000-0001-9849-9273 (Российская Федерация,

119571, г. Москва, пр. Вернадского, д.82; e-mail: zinov-v@yandex.ru)

\section{O.A. EREMCHENKO,}

Russian Presidential Academy of National Economy and Public Administration

(Moscow, Russian Federation; e-mail: tatrics@mail.ru)

\section{V.G. ZINOV,}

Russian Presidential Academy of National Economy and Public Administration

(Moscow, Russian Federation; e-mail: zinov-v@yandex.ru)

\section{STATE SUPPORT FOR THE VENTURE INDUSTRY: GLOBAL PRACTICE}

\author{
UDC: 338 \\ https://doi.org/10.22394/2410-132X-2021-7-1-51-65
}

Abstract: The experience and features of state models of support for the corporate venture sector in the USA, China, and EU countries are summarized. A general trend in the development of the venture capital industry for foreign countries is the shift in the focus of venture capital funds to investments of late stages of financing. It is shown that the greatest efficiency of government programs in stimulating large companies to innovative and technological development is achieved with joint financing of startups, with the creation of a venture capital fund, with the introduction of tax incentives aimed at companies with high growth potential.

Keywords: venture capital, corporate venture funds, investments, government support programs, technological development, fund of funds, tax incentives

Acknowledgements: The study was carried out within the framework of the state assignment of the RANEPA. For citation: Eremchenko O.A., Zinov V.G. State Support for The Venture Industry: Global Practice. The Economics of Science. 2021; 7(1):51-65. https://doi. org/10.22394/2410-132X-2020-7-1-51-65

\section{REFERENCES}

1. The list of instructions of the President of the Russian Federation following the results of the St. Petersburg International Economic Forum dated 14.06.2017 No. Pr-1132 (2017) / Official website of the President of Russia. http://www.kremlin.ru/acts/assignments/orders/54793. (In Russ.)

2. Instructions based on the results of the meeting with the members of the Expert Council under the Government and the community representation on the development of innovations (2014) / Official website of the Government of Russia, 13.08.2014. http://government.ru/orders/selection/401/14277. (In Russ.)

3. List of instructions following the meeting with leading Russian investors (approved by the President of the Russian Federation dated 01.04.2020, No. Pr-614)
(2020) / Consultant Plus. http://www.consultant.ru/ document/cons doc LAW_349280. (In Russ.)

4. The 2020 Global CVC Report (2021) / CB Insights, 16.03.2021. https://www.cbinsights.com/research/ report/corporate-venture-capital-trends-2020.

5. The 2018 Global CVC Report (2019) / CB Insights. https://www.cbinsights.com/research/report/corporate-venture-capital-trends-2018.

6. Jean L., Sahut J., Teulon F. (2011) What is the real role of corporate venture capital? // International Journal of Business. 16(4):367-382.

7. Chesbrough H.W., Tucci C.L. (2004) Corporate Venture Capital in the Context of Corporate Innovation / DRUID Summer Conference 2004. Elsinore, Denmark. 
8. Lerner J., Nanda R. (2020) Venture Capital's Role in Financing Innovation: What We Know and How Much We Still Need to Learn / Working Paper 20-131. Harvard Business School. 32 p.

9. Lerner J. (2009) Boulevard of Broken Dreams. Why Public Efforts to Boost Entrepreneurship and Venture Capital Have Failed - and What to Do about It / Princeton University Press.

10. Venture Monitor Q4 2020 (2021) / PitchBook, NVCA. 37 p.

11. Corasaniti N. (2018) With $\$ 500$ Million, New Jersey Wants to Invest in Your Start-Up / The New York Times, 01.10.2018. https://www.nytimes. com/2018/10/01/nyregion/new-jersey-venturecapital-murphy.html.

12. State Small Business Credit Initiative (2021) / U.S. Department of the Treasury. https://www.treasury.gov/resource-center/sb-programs/Pages/ ssbci.aspx.

13. Appendices. Program Evaluation of the U.S. Department of Treasury State Small Business Credit Initiative Center for Regional Economic Competitiveness \& Cromwell Schmisseur (2016) / U.S. Department of the Treasury. https://www.treasury. gov/resource-center/sb-programs/Documents/ SSBCI\%20Program\%20Evaluation $\% 202016 \% 20$ -\%20Appendices.pdf.

14. Investment Taxation. Venture Capital: The U.S. Tax Regime For Venture Capital (2021) / LowTax. https://www.lowtax.net/us-tax-guide/investment/ the-us-tax-regime-for-venture-capital.html.

15. The Committee on Foreign Investment in the United States (2021) / U.S. Department of the Treasury. https://home.treasury.gov/policy-issues/international/the-committee-on-foreign-investment-in-theunited-states-cfius.

16. Lerner J. (2010) The future of public efforts to boost entrepreneurship and venture capital // Small Business Economics. 35(3):255-264.

17. Owen R., North D., Mac C. (2019) The Role of Government Venture Capital Funds: Recent lessons from the UK experience. https://onlinelibrary.wiley. com/doi/full/10.1002/isc.2247.

18. From Funding Gaps to Thin Markets: UK Government Support for Early-Stage Venture Capital (2009) / BVCA Report for NESTA. 36 p.

19. The Capital Behind Venture 2020. Insights from the investors behind Europe's Venture Capital Ecosystem (2021) / Mountside Venture, Allocate. 27 p.
20. The State of European Tech 2019 Report (2020) / Atomico, 2020

21. World Wealth Report (2020) / Capgemini. https:// worldwealthreport.com.

22. Serenelli L. (2021) German government quick starts fund with $€ 10 \mathrm{bn}$ for 'future tech' / IPE, 30.03.2021. https://www.ipe.com/news/germangovernment-quick-starts-fund-with-10bn-for-futuretech/10051949.article.

23. Partington M. (2020) Germany launches $€ 10 \mathrm{bn}$ 'Future Fund' for startups. But will it go far enough? / Sifted, 14.12.2020. https://sifted.eu/articles/germany-future-fund-startups.

24. Murray G.C. (2007) Venture Capital and Government Policy / In Handbook of Research on Venture Capital, edited by H. Landstrom. Pp. 113-151.

25. Effectiveness of tax incentives for venture capital and business angels to foster the investment of SMEs and start-ups. Final Report (2017) / European Communities. https://ec.europa.eu/taxation_customs/sites/taxation/files/taxation_paper 69 vc-ba.

26. Blank S. (2021) China Startup Report: Intrōuction to Chinese Venture Capital (Part 3 of 5) / StartupGrind. https://www.startupgrind.com/blog/chinastartup-report-introduction-to-chinese-venture-capital-part-3-of-5.

27. Zinser S. (2021) The Global Reach of China's Venture Capital / The Diplomat, 21.01.2021. https:// thediplomat.com/2021/01/the-global-reach-ofchinas-venture-capital.

28. McBride J., Chatzky A. (2019) Is 'Made in China 2025' a Threat to Global Trade? // Council of Foreign Relations. 13.05.2019. https://www.cfr. org/backgrounder/made-china-2025-threat-global-trade\#: : : text=China $\% 202025 \% 20$ sets $\% 20$ specific\%20targets, dominant $\% 20$ position $\% 20$ in $\% 20$ global\%20markets.

29. Huang T. (2019) Government-Guided Funds in China: Financing Vehicles for State Industrial Policy / PIIE, 17.06.2019. https://www.piie.com/blogs/ china-economic-watch/government-guided-fundschina-financing-vehicles-state-industrial-policy.

30. Wu Y.B. (2017) Distorted investment under Chinese style decentralization // Economics Research Journal. 52(06): 137-152 (in Chinese).

31. Shi X., Bu D., Zhang C. (2020) Official rotation and corporate innovation: Evidence from the governor rotation // China Journal of Accounting Research. 13(4):361-385.

\section{Authors}

Eremchenko Olga Andreevna - Senior Researcher of the Center for Scientific and Technical Expertise, The Russian Presidential Academy of National Economy and Public Administration; Scopus Author ID: 5581 1482100, ORCID: 0000-0001-5964-9080 (Russian Federation, 119571, Moscow, Vernadsky Pr., 82; e-mail: tatrics@mail.ru)

Zinov Vladimir Glebovich - Chief Researcher of the Center for Scientific and Technical Expertise, The Russian Presidential Academy of National Economy and Public Administration; Scopus Author ID: 7003590126,

ORCID: 0000-0001-9849-9273 (Russian Federation, 119571, Moscow, Vernadsky Pr., 82; e-mail: zinov-v@yandex.ru) 